The Political Economy of China's Changing Relations with Southeast Asia 


\section{The Political Economy of China's Changing Relations with Southeast Asia}

\section{JOHN WONG}


ISBN 978-0-333-28686-9 ISBN 978-1-349-27929-6 (eBook)

DOI 10.1007/978-1-349-27929-6

(C) John Wong 1984

Softcover reprint of the hardcover 1st edition 1984

All rights reserved. For information, write:

St. Martin's Press, Inc., 175 Fifth Avenue, New York, NY 10010

Published in the United Kingdom by The Macmillan Press Ltd

First published in the United States of America in 1984

ISBN 978-0-312-62258-9

\section{Library of Congress Cataloging in Publication Data}

Wong, John, 1939-

The political economy of China's changing relations with Southeast Asia.

Includes bibliographical references and index.

1. China-Foreign economic relations-Asia, Southeastern. 2. Asia, Southeastern-Foreign economic relations-China. I. Title.

HF1604.Z4A7858 $1984 \quad 337.51059 \quad 83-40198$

ISBN 978-0-312-62258-9 
To Aline, Tien Yin and Tien Hua 


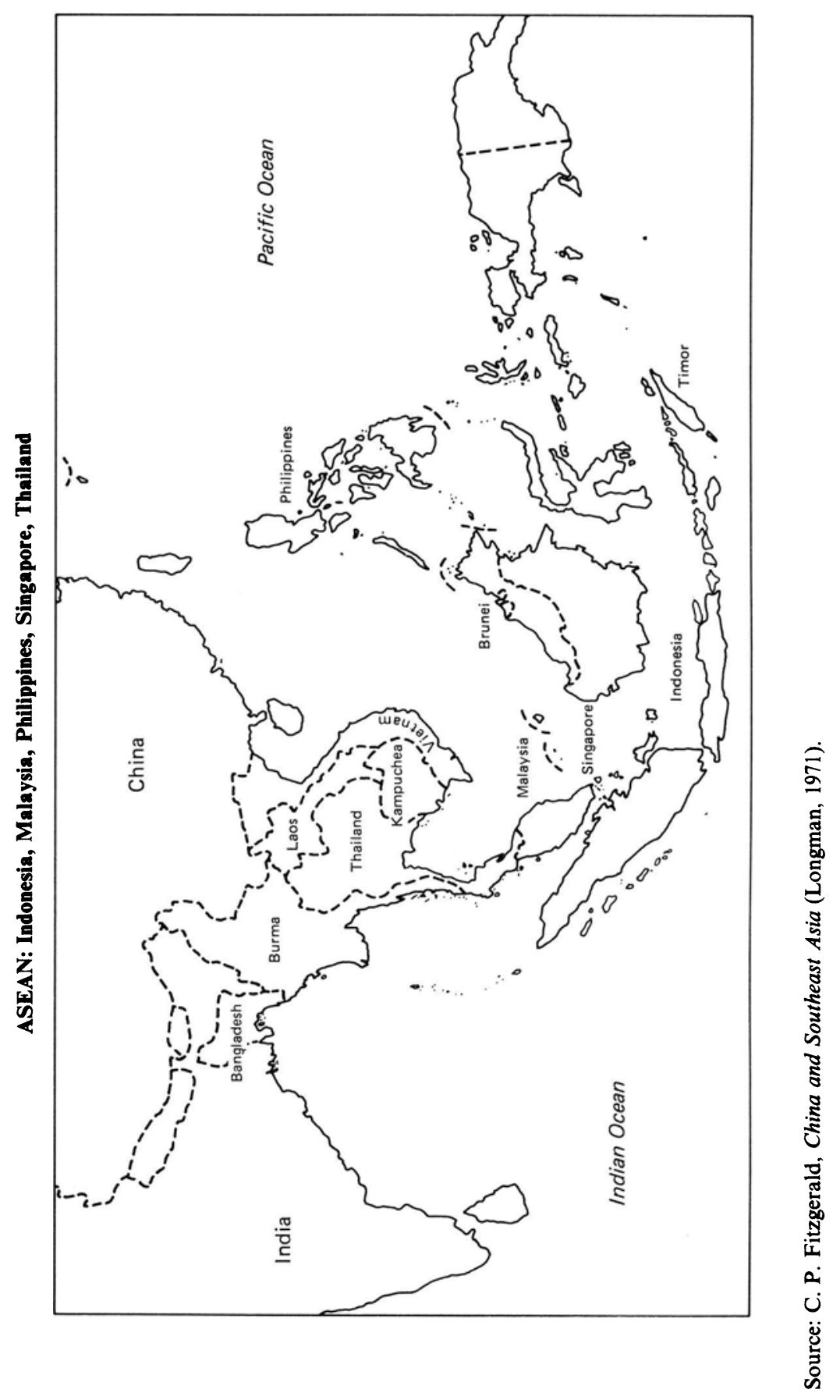




\section{Contents}

Preface

List of Abbreviations $\quad$ xv

1 CHINA'S ECONOMIC RELATIONS WITH SOUTHEAST ASIA: CHANGING DIMENSIONS 1 Historical Backgrounds 1

China and ASEAN in Comparative Perspective 10

Pattern of Sino-ASEAN Trade 12

China's Drive to Economic Modernisation 15

Complementary Demands vs Competitive Supplies 20

The primary-commodity balance in China's trade 21

Competitive pressures on manufactured exports $\quad 24$

2 INDONESIA'S RELATIONS WITH CHINA 31

Introduction 31

Early Relations $\quad 34$

Relations during 'Constitutional Democracy' 37

Crises under 'Guided Democracy' $\quad 40$

The 'Beijing-Jakarta Axis' 45

The Growth and Structure of Sino-Indonesian Trade 48

Sluggish Return to Normality 53

The Logic of Diplomatic Impasse $\quad 60$

3 MALAYSIA/SINGAPORE'S RELATIONS WITH CHINA - I $\quad 65$

Introduction $\quad 65$

Development of Pan-Malaya's Trade with China, 1950-66 69 
viii

\section{Contents}

Politics and Economics of Trade 75

Embargo $\quad 77$

Dumping $\quad 79$

Confrontation $\quad 85$

The Bank of China incident $\quad 88$

4 MALAYSIA/SINGAPORE'S RELATIONS WITH

CHINA - II 92

Transition to Normalisation $\quad 92$

Malaysia $\quad 93$

Singapore $\quad 97$

The Pattern of Trade $\quad 100$

Growth and structure $\quad 100$

$\begin{array}{ll}\text { Trade fluctuations } & 107\end{array}$

Chinese demand for rubber $\quad 109$

Issues and Problems 113

Singapore's Role 119

5 THE PHILIPPINES' RELATIONS WITH CHINA 123

Introduction 123

Early Commercial Relations $\quad 125$

The Cold War Era $\quad 126$

The Road to Normalisation 131

Sino-Philippine Trade $\quad 140$

Issues in Sino-Philippine Relations 144

6 THAILAND'S RELATIONS WITH CHINA 150

Introduction $\quad 150$

Historical Background to Sino-Thai Relations 152

The Pattern of Early Trade $\quad 154$

Non-Recognition Period 156

Mutual Antagonism and Avoidance $\quad 162$

The Road to Normalisation 165

Pattern and Structure of Sino-Thai Trade 175

Issues and Problems 178

Tables 183

Notes and References $\quad 220$

Index 237 


\section{Preface}

President Nixon's visit to Beijing (Peking) ten years ago ushered in a new era of international politics for Southeast Asia, particularly in its overall relations with the People's Republic of China. Nixon's trip quickened the opening up of China, which in the aftermath of the Cultural Revolution also increasingly felt the need to coexist with countries in Southeast Asia on a non-ideological basis. But the impact has been more dramatic for countries in Southeast Asia. Following the 'Nixon shock', these countries had to be reconciled to the reality of the shift of the political balance brought about by the thawing of the Cold War and sought more realistic ways and means to live with China as a powerful neighbour to their north, operated under a different social and economic system. Hence the process of normalisation.

I started to modify my academic interest in China from the primary concern with its domestic economic problems to its external economic relations with Southeast Asia at the time when the détente was about to unfold itself in the region. I was able to watch and document the many exciting events which cropped up from the efforts of countries in Southeast Asia to normalise their relations with China. In retrospect, normalisation has not been a smooth process but one fraught with a lot of political twists and turns especially during the initial periods. Meanwhile, my own research focus has increasingly 
broadened to include Southeast Asian economic studies, which has thus enabled me to relate the 'China problem' for each of these Southeast Asian countries to its specific political and economic context. Consequently this study could perhaps claim one rather unique feature, which is the way it attempts to blend 'China scholarship' with 'Southeast Asia scholarship' and to offer a distinct and balanced perspective on Sino-Southeast Asian issues so as to be different from the view held by either a China expert working on primary source materials from China or a Southeast Asian specialist taking into consideration often narrowly based country-specific standpoints.

This study is primarily concerned with the economic aspects of China's relations with the five Southeast Asian countries - namely, Indonesia, Malaysia, the Philippines, Singapore and Thailand which together constitute the Association of Southeast Asian Nations (ASEAN). Strictly speaking, the main focus is on their trade relations with China, as their economic interaction in other areas has not been significantly developed. In order to bring about a more comprehensive treatment of the subject, a political economy approach is adopted. Economic relations among states, even for those functioning on liberal market forces, are seldom confined to the simple exchange of goods and services. In particular, the primary role of politics cannot be ruled out from any discussion of economic relations between a socialist economy and a market economy. It would be a highly uninspiring as well as unrealistic and narrow exercise if this book were to take the easy way out by just analysing the structure and patterns of China's trade with the ASEAN countries on the basis of published trade statistics and then drawing its conclusions within a certain neo-classical economic framework such as the maximisation of economic welfare or other forms of trade-off from trade.

As Professor Peter Wiles has stressed, foreign economic relations of states are basically a political act and an economist should make no apology in trespassing beyond the borders of so-called 'pure economics', for 'such borders, like international ones, exist only to be trampled upon'.* I have therefore not hestitated to venture boldly into the discipline of international relations in order to capture the related elements at work. Except for Chapter 1, which is fully devoted

* See P. J. D. Wiles, Communist International Economics (Oxford: Basil Blackwell, 1968) Preface. 
to the economic analysis of the overall pattern of China's economic relations with ASEAN in a more standard manner, the other five chapters, dealing with China's bilateral relations with the individual ASEAN countries, follow a distinct political economy approach. In these five chapters, I try first to depict a broad picture of China's overall relations with each of the five ASEAN countries through the past three decades and then analyse the trade pattern and trade behaviour against the underlying political events or whatever relevant institutional forces are at work. On certain issues I have gone into some lengths for their historical backgrounds. I believe that a proper historical perspective would render it less hazardous to assess the present status of some policy issues as well as provide a coherent framework to test their consistency. Many thorny problems that have persistently bedevilled the present Sino-ASEAN relationship are in fact rooted in their past. The Sino-Indonesian diplomatic impasse is a case in point. Neither economic logic nor political arguments, however cogent, can adequately explain the unwillingness on the part of the present Indonesian leadership to re-establish ties with Beijing. But historical factors can throw much light on this issue.

It will be noted that this book is based on source materials emanating essentially from the Southeast Asian region, with minimum reliance on official data from China. I have also drawn from such regional publications as the Far Eastern Economic Review. Those with experience in area studies will readily appreciate that the great challenge for the groundwork research for this kind of scholarly pursuit lies not just in laboriously bringing together scattered information from often disparate local sources but also in the meticulous sifting and interpreting of the arrayed materials. It is well known that some local information of the 1950s and the 1960s, when the region was under the influence of the Cold War, is heavily biased and is replete with much political rhetoric. It is therefore imperative that such information be subjected to careful scrutiny and balanced interpretation.

Historically, China and Southeast Asia have been dealing with each other for centuries, and the past three turbulent decades covered in 
this book constitute but a brief interlude in their age-old relationship. Now the demise of the Cold War has finally restored their relationship to the level of normality, with both sides being willing to come to terms with each other. But the apparent stability in the overall relationship existing between China and the ASEAN countries should not be taken for granted. The shape of their future relations for the rest of the 1980s is still clouded by a great deal of uncertainty. A sharp deterioration of Sino-American relations or a rapid rapprochement between China and the Soviet Union could well estrange ASEAN from China. The Indochina situation would be another unstable parameter. As for China's bilateral relations with the individual ASEAN countries, the potential volatility is likely to stem from domestic developments in the ASEAN countries. For instance, a resurgence of the Communist movement in a specific ASEAN country or a mishandling of the ethnic Chinese issue by Beijing could easily rock China's existing relations with that ASEAN country. After all, China is still a Communist country, while all the ASEAN countries are not. This very basic difference would be enough to throw both sides back to the vortex of confrontational relations at the slightest provocation.

While Sino-ASEAN relations on the political level could easily succumb to unpredictable forces, their economic relationship seems to be facing better prospects for stability. The economic ties between China and ASEAN have been steadily strengthened in recent years. Furthermore, the economic intercourse has tended to detach from the past political and ideological entanglement and thus become more resilient to adverse political developments. Take Sino-ASEAN trade. It is in the process of getting into the upward spiral of trade and growth in the sense that as economic growth in China and in the ASEAN countries gets further underway, their two-way trade will also steadily expand. It is therefore not unrealistic to foresee the mildly optimistic scenario of a gradual broadening of Sino-ASEAN economic relationships throughout the 1980s even in the absence of a deepening of Sino-ASEAN political understanding. A substantial growth of economic interdependence will in the long run create the realpolitik condition for a more stable and durable political relationship. 
III

I am grateful to the Stiftung Volkswagenwerk of West Germany for a generous research grant which enabled me to travel around the ASEAN countries and Hong Kong to collect and update materials for this book. Earlier, the Harvard-Yenching Institute of Harvard University had been kind enough to fund several of my research projects directly related to the topic of this book. To these two bodies I wish to express my gratitude.

Singapore

John Wong 


\section{List of Abbreviations}

$\begin{array}{ll}\text { ADC } & \text { Advanced Developing Countries } \\ \text { APACL } & \text { Asian People's Anti-Communist League } \\ \text { ASEAN } & \text { Association of Southeast Asian Nations } \\ \text { CCP } & \text { Chinese Communist Party } \\ \text { EDB } & \text { Economic Development Board } \\ \text { FEER } & \text { Far Eastern Economic Review } \\ \text { GANEFO } & \text { Games of the New Emerging Forces } \\ \text { GDP } & \text { Gross Domestic Product } \\ \text { GNP } & \text { Gross National Product } \\ \text { HKS } & \text { Hong Kong Standard } \\ \text { MAAG } & \text { Military Advisory Assistance Group } \\ \text { MCP } & \text { Malayan Communist Party } \\ \text { MFA } & \text { Multi-Fiber Arrangement } \\ \text { MFN } & \text { Most Favoured Nation } \\ \text { MNC } & \text { Multi National Company } \\ \text { NASAKOM Nationalism, Islam and Communism } \\ \text { NEC } & \text { National Executive Council } \\ \text { NIC } & \text { Newly Industrialised Country } \\ \text { ODA } & \text { Official Development Assistance } \\ \text { OECD } & \text { Organisation for Economic Co-operation and } \\ & \text { Development } \\ \text { PAP } & \text { People's Action Party } \\ \text { PKI } & \text { Partai Komunis Indonesia (Indonesian Communist } \\ & \text { Party) } \\ \text { SEATO } & \text { South East Asia Treaty Organisation }\end{array}$


SMR Standard Malaysian Rubber

SSR Standard Singapore Rubber

ST Straits Times

UMNO United Malay National Organisation

UN United Nations

A Note on Currency

$$
\text { Unit mid-1983, per US dollar }
$$

China Yuan or Renminbi

$\begin{array}{llr} & \text { (RMB) } & 1.98 \\ \text { Indonesia } & \text { Rupiah } & 965 \\ \text { Malaysia } & \text { Ringgit or Malaysian } & \\ & \text { dollar (M\$) } & 2.33 \\ \text { Philippines } & \text { Peso } & 11.02 \\ \text { Singapore } & \text { Singapore dollar (S\$) } & 2.13 \\ \text { Thailand } & \text { Baht } & 23\end{array}$

